\title{
STANDARISASI VITAMIN C PADA BUAH BENGKUANG (Pachyrhizus erosus) SECARA SPEKTROFOTOMETRI UV-VIS
}

\author{
Harti Widiastuti \\ Fakultas Farmasi, Universitas Muslim Indonesia \\ e-mail : harti_widiastuti@yahoo.com
}

\begin{abstract}
Have been conducted by a obstetrical research of vitamin $C$ at juicy tuber by spectrophotometry UV - Vis. The research aim to determine and compare the content of vitamin $C$ from juicy tuber. Firstly fruit of juicy tuberare cleared by their seed then it weighed after that it enhanced by oxilate acid $0.4 \%$ and than it blended and filtered. Filtrat obtained to qualitative analyze by using the react specific and standarization of vitamin $C$ using the spectrophotometry UV - Visible at wave legth $516 \mathrm{~nm}$ obtained rate of mean vitamin $C$ that is juicy tuber yaitu $91.97 \mathrm{mg} / 100 \mathrm{~g}$.
\end{abstract}

Keywords : Vitamin C, Juicy Tuber, Spectrophotometry UV - Vis

\section{PENDAHULUAN}

\section{Latar Belakang}

Vitamin C merupakan salah satu vitamin yang diperlukan oleh tubuh dan berfungsi untuk meningkatkan sistem imunitas tubuh. Bila dalam tubuh kebutuhan vitamin dan mineral mencukupi, maka segala jenis penyakit dapat dicegah. Mengkonsumsi vitamin $\mathrm{C}$ yang juga berfungsi sebagai antioksidan terbukti dapat menangkal virus-virus seperti virus flu, selain itu vitamin $\mathrm{C}$ juga berfungsi sebagai sistem pertahanan tubuh yang bertanggung jawab penuh terhadap setiap gangguan pada tubuh baik gangguan psikis (misalnya stres, sedih, marah), fisik (seperti terluka, kelelahan, sakit), fisiologi (contohnya asupan zat anti gizi bersama makanan, kasus salah gizi), maupun lingkungan sekitar (diantaranya udara kotor, asap rokok, kebisingan).

Vitamin C sangat dibutuhkan, terutama di kota besar. Belum lagi radikal bebas berupa polusi dari asap kendaraan bermotor dan rokok, serta lainnya, makin bertebaran. Semua itu membuat tubuh rentan terhadap berbagai gangguan kesehatan. Daya tahan mudah menurun dan serangan radikal bebas membuat sel-sel tubuh mudah rusak dan tak mampu berfungsi dengan baik. Salah satu akibat dari proses kerusakan secara cepat itu adalah penuaan kulit lebih dini.
Pachyrhizus erosus atau yang lebih dikenal sebagai bengkuang adalah salah satu buah-buahan yang berasal dari wilayah Amerika tropis termasuk dalam suku polong-polongan. Umbi putihnya biasa dikonsumsi sebagai sayuran dan kripik bengkuang atau dijadikan masker untuk menyegarkan wajah dan memutihkan kulit.. Selain itu jus bengkuang dapat digunakan untuk pengobatan diabetes mellitus, sariawan, wasir, demam dan dapat menurunkan kadar kolesterol darah. Berdasarkan hal tersebut maka dilakukan penelitian analisis kadar vitamin $\mathrm{C}$ pada buah bengkuang (Pachyrhizus erosus) secara spektrofotometri UV-Vis.

\section{METODE PENELITIAN}

A. Penyiapan Sampel

Pada penelitian ini, digunakanbuah bengkuang (Pachyrhizus erosus) yang dicuci bersih terlebih dahulu, dipotong lalu kulitnya dikupas. Ditimbang sebanyak 50,0 gram kemudian dimasukkan kedalam blender lalu ditambahkan $100 \mathrm{ml}$ larutan asam oksalat $0,4 \%$ kemudian diblender sampai halus lalu disaring untuk memisahkan residu dan filtratnya. Filtrat diambil dan dimasukkan dalam labu tentukur $500 \mathrm{ml}$, dan cukupkan volumenya dengan larutan asam oksalat $0,4 \%$ hingga batas tanda. 
B. Pemeriksaan kualitatif Vitamin C

1. Pereaksi iodium

Sampel ditambahkan larutan pereaksi iodium, warna iodium akan hilang jika mengandung vitamin $\mathrm{C}$.

\section{Pereaksi 2,6 - diklorofenol indofenol}

Sampel mengandung vitamin $\mathrm{C}$ jika sampel ditambahkan dengan larutan pereaksi 2,6 - diklorofenol akan berwarna merah muda atau ungu.

\section{Pereaksi Fehling A dan Fehling B}

Larutan contoh ditambahkan dengan pereaksi fehling A dan fehling B sama banyak, lalu dipanaskan terjadi endapan merah bata.

\section{Pereaksi besi (III) klorida}

Larutan contoh ditambahkan dengan pereaksi Besi (III) klorida terbentuk warna kuning dibiarkan akan hilang.

\section{Standarisasi Vitamin C Secara Spektrofotometri UV-Vis}

\section{Pembuatan larutan Baku vitamin $C$} Ditimbang dengan teliti 100,0 mg asam askorbat murni kemudian dimasukkan ke dalam labu tentukur 100,0 ml lalu dilarutkan dengan asam oksalat 0,4\% hingga 100,0 ml (1000 bpj).

\section{Penentuan panjang gelombang maksimum \\ Dipipet sebanyak $10 \mathrm{ml}$ larutan} baku asam askorbat dimasukkan kedalam labu ukur $100 \mathrm{ml}$, dilarutkan dengan asam oksalat $0,4 \%$ hingga tanda garis sehingga konsentrasinya menjadi 100bpj. Dipipet 25 $\mathrm{ml}$ larutan dimasukkan kedalam labu tentukur $50 \mathrm{ml}$, kemudian dilarutkan dengan asam oksalat $0,4 \%$ hingga tanda garis sehingga konsentrasi menjadi 50 bpj. Dipipet $1 \mathrm{ml}$ larutan dimasukkan dalam labu ukur $10 \mathrm{ml}$ dan ditambahkan larutan 2,6 diklorofenol indofenol sampai tanda garis, dikocok dan segera dilakukan pengukuran spektrofotometer UV-Vis dengan panjang gelombang $516 \mathrm{~nm}$.

\section{Pembuatan kurva baku}

Larutan asam askorbat $50 \mathrm{bpj}$ dipipet sebanyak 2, 3, 4 dan $5 \mathrm{ml}$ dimasukkan kedalam labu ukur $10 \mathrm{ml}$ masing-masing larutan ditambahkan $4 \mathrm{ml}$ 2,6-diklorofenol indofenol dan dicukupkan volumenya dengan asam oksalat $0,4 \%$ hingga tanda. Diperoleh masing-masing konsentrasi 4; 6; 8; 10 bpj. Kemudian diukur serapanya pada panjang gelombang $516 \mathrm{~nm}$.

\section{Pengukuran kadar vitamin $\mathrm{C}$}

Larutan contoh dipipet sebanyak 1,0 ml kemudian dimasukkan ke dalam labu tentukur $10 \mathrm{ml}$. Setelah itu ditambahkan dengan 2,6 - diklorofenol indopenol hingga batas tanda kemudian dikocok hingga homogen lalu diukur serapannya pada panjang gelombang $516 \mathrm{~nm}$.

\section{Perhitungan kadar vitamin $\mathbf{C}$}

Perhitungan kadar vitaminC dilakukan dengan cara mengekstrapolasikan data serapan vitamin $\mathrm{C}$ pada persamaan regresi linear dari kurva baku vitamin $\mathrm{C}$.

\section{HASIL DAN PEMBAHASAN}

A. Hasil Penelitian

Tabel 1. Hasil Pemeriksaan Kualitatif Vitamin C Pada Buah Bengkuang (Pachyrhizus erosus)

\begin{tabular}{|c|c|c|c|c|}
\hline No. & Pereaksi & Hasil & Pustaka & Keterangan \\
\hline 1. & P1 & $\begin{array}{c}\text { Warna } \\
\text { iodium } \\
\text { hilang }\end{array}$ & $\begin{array}{c}\text { Warna } \\
\text { iodium } \\
\text { hilang }\end{array}$ & Positif (+) \\
\hline 2. & P2 & $\begin{array}{c}\text { Warna } \\
\text { merah } \\
\text { muda }\end{array}$ & $\begin{array}{c}\text { Warna } \\
\text { merah } \\
\text { muda }\end{array}$ & Positif (+) \\
\hline 3. & P3 & $\begin{array}{c}\text { Warna } \\
\text { kuning } \\
\text { hilang }\end{array}$ & $\begin{array}{c}\text { Warna } \\
\text { kuning } \\
\text { hilang }\end{array}$ & Positif (+) \\
\hline 4. & P4 & $\begin{array}{c}\text { Warna } \\
\text { merah } \\
\text { bata }\end{array}$ & $\begin{array}{c}\text { Warna } \\
\text { merah } \\
\text { bata }\end{array}$ & Positif (+) \\
\hline
\end{tabular}

Keterangan :

Pereaksi (P1) : Iodium

Pereaksi (P2) : 2,6-diklorofenol indofenol

Pereaksi (P3) : Besi (III) klorida

Pereaksi (P4) : Fehling A dan B

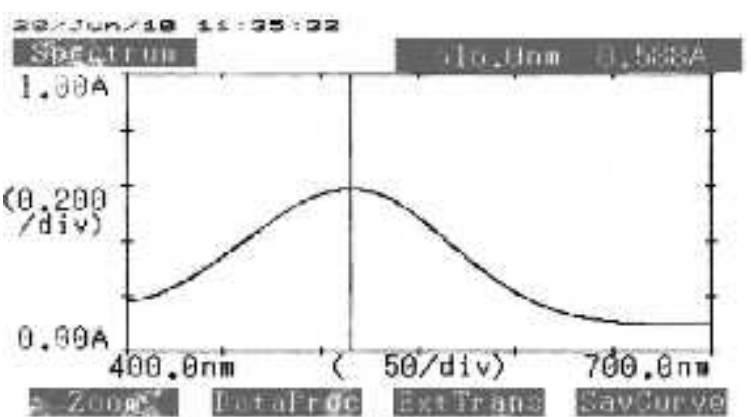


Gambar 1. Spektrum Absorban Baku Vitamin C Menggunakan Spektrofotometer UV-VIS

Vitamin C memiliki serapan maksimum pada panjang gelombang 516 nm. Oleh karena itu pada pengerjaan selanjutnya digunakan panjang gelombang $516 \mathrm{~nm}$.

Tabel 2. Hasil Pengukuran Serapan Larutan Baku Asam Askorbat Secara Spektrofotometri UV- Visible Pada Panjang Gelombang 516nm

\begin{tabular}{|c|c|c|}
\hline No & Konsentrasi & Absorban \\
\hline 1 & 4 & 0,308 \\
2 & 6 & 0,538 \\
3 & 8 & 0,698 \\
4 & 10 & 0,865 \\
\hline
\end{tabular}

Diperoleh Persamaan regresi : $\mathrm{y}=$ 0,0916x - 0,0386, dengan koefisien korelasi $=0,996$.

Tabel 3. Hasil Analisis Kuantitatif Vitamin C Pada Buah Bengkuang (Pachyrhizus erosus) Secara Spektrofotometri UV-Vis.

\begin{tabular}{|c|c|c|c|c|c|}
\hline Sampel & $\begin{array}{c}\text { Berat } \\
\text { Contoh }(\mathbf{g})\end{array}$ & $\begin{array}{c}\text { Absorban } \\
(\mathbf{A})\end{array}$ & $\begin{array}{c}\text { Kadar } \\
(\mathbf{m g} / \mathbf{g})\end{array}$ & $\begin{array}{c}\text { Kadar } \\
(\mathbf{m g} / \mathbf{1 0 0} \mathbf{g})\end{array}$ & $\begin{array}{c}\text { Kadar rata-rata } \\
(\mathbf{m g} / \mathbf{1 0 0 g})\end{array}$ \\
\hline Buah & & 0,810 & 0,9262 & 92,62 & \\
bengkuang & & 0,804 & 0,9197 & 91,97 & 91,97 \\
(Pachyrhizus & 50,01 & 0,798 & 0,9131 & 91,31 & \\
erosus $)$ & & &
\end{tabular}

\section{B. PEMBAHASAN}

Penelitian ini bertujuan untuk menentukan kadar vitamin $\mathrm{C}$ padabuah bengkuang (Pachyrhizus erosus)secara Spektrofotometri UV-Vis. Dimana keuntungan vitamin $\mathrm{C}$ untuk perlindungan terhadap system kekebalan tubuh, berbagai penyakit kardiovaskuler, masalah mata, dan bahkan kesehatan kulit. Sebelum dilakukan penelitian, terlebih dahulu dilakukan pengambilan dan pengamatan terhadap sampel buah bengkuang (Pachyrhizus erosus). Buah yang dipilih harus memiliki kualitas yang baik, yaitu buah yang segar, tekstur buah keras, bentuk buah normal (tidak mengkerut), tidak cacat, Kulitnya masih licin, mengkilat,dan tidak kusam serta tidak terinfeksi hama dan penyakit.

Penelitian ini dilakukan uji kualitatif dan uji kuantitatif, dimana terlebih dahulu dilakukan penyiapan larutan sampel bengkuang (Pachyrhizus erosus)dicuci dengan air suling, dikupas, daging buahnya dipotong-potong kemudian ditimbang, sampel tersebut diblender dan dilarutkan dengan menggunakan asam oksalat 0,4\%. Asam oksalat berguna sebagai pelarut untuk mencegah teroksidasinya vitamin $\mathrm{C}$ dalam pengolahan. Vitamin $\mathrm{C}$ dapat bereaksi dengan pereduksi yang kuat seperti asam oksalat sehingga vitamin $\mathrm{C}$ yang teroksidasi yakni asam dehidroaskorbat dapat menjadi asam askorbat kembali dengan demikian dapat dilakukan penetapan kadar vitamin $\mathrm{C}$ secara maksimal

Analisis kualitatif dilakukan dengan menggunakan beberapa pereaksi yang spesifik dengan tujuan untuk mengetahui ada atau tidaknya vitamin $\mathrm{C}$ pada buah bengkuang (Pachyrhizus erosus). Adapun pereaksi spesifik yang digunakan yaitu Iodium, 2,6-diklorofenol indofenol, Besi (III) klorida dan Fehling A dan B. Hasil yang diperoleh semuanya positif sesuai dengan pustaka. Pereaksi Iodum ditunjukkan dengan hilangnya warna iodium.Dengan pereaksi 2,6-diklorofenol indofenol terbentuk warna merah muda, reaksi ini didasarkan atas tereduksinya 2,6diklorofenol indofenol oleh vitamin $\mathrm{C}$ membentuk dehidro asam askorbat dan indofenol tereduksi menjadi dehidro 2,6diklorofenol indofenol. Dengan pereaksi besi (III) klorida menjadi larutan kuning yang lama kelamaan akan hilang, ini disebabkan karena vitamin $\mathrm{C}$ mereduksi $\mathrm{Fe}^{+3}$ (ferri) menjadi $\mathrm{Fe}^{+2}$ (ferro). 
Pada analisis kuantitatif sampel diblender dan dilarutkan dengan menggunakan asam oksalat 0,4\%. Asam oksalat ini berguna untuk mencegah pengaruh ion tembaga sehingga dapat bereaksi dengan 2,6-diklorofenol indofenol yang akan terukur menjadi vitamin $\mathrm{C}$, dalam hal ini yang akan teroksidasi setara dengan 2,6-diklorofenol indofenol, yang tereduksi diperoleh dari hasil pengurangan 2,6diklorofenol indofenol awal dengan diklorofenol indofenol yang bereaksi dengan asam oksalat menjadi tidak berwarna. Penetapan kadar menggunakan Spektromotometer Visible menggunakan pereaksi 2,6-diklorofenol indofenol pada buah bengkuang (Pachyrhizus erosus), reaksi ini didasarkan atas pengukuran jumlah larutan 2,6-diklorofenol indofenol yang dihilangkan warnanya oleh vitamin $\mathrm{C}$. Intensitas warna dari 2,6-diklorofenol indofenol sangat tergantung terhadap waktu, karena hasil reaksi dari 2,6-diklorofenol indofenol dengan vitamin $\mathrm{C}$ semakin lama semakin hilang. Hal ini dapat mempengaruhi pada absorbansi yang diperoleh dan secara langsung yang akan mempengaruhi dalam penetapan kadar.

Kadar rata-rata vitamin $\mathrm{C}$ yang diperoleh pada buah bengkuang (Pachyrhizus erosus) adalah 91,97 mg/100 gr. Menurut literatur kandungan vitamin $\mathrm{C}$ pada buah bengkuang (Pachyrhizus erosus) yaitu $17,7 \mathrm{mg} / 100 \mathrm{~g}$ hasil ini berbeda dengan hasil penelitian yang telah dilakukan. Perbedaan tersebut disebabkan karena adanya beberapa faktor diantaranya perbedaan waktu panen, iklim, tanah dan perbedaan tempat tumbuh.

\section{KESIMPULAN}

Dari hasil penelitian yang telah dilakukan dapat diambil kesimpulan bahwa:

1. Buah bengkuang (Pachyrhizus erosus) mengandung vitamin $\mathrm{C}$

2. Kadar vitamin $\mathrm{C}$ dari buah bengkuang (Pachyrhizus erosus) adalah $91,76 \mathrm{mg} / 100 \mathrm{gr}$.

\section{DAFTAR PUSTAKA}

1. Almatsier Sunita. 2003. Prinsip-Prinsip Dasar Ilmu Gizi. PT Gramedia Pustaka Utama, Jakarta

2. Arianto. 2010. artikel pengertian dan manfaat bengkuang. (online), (http://sobatbaru.blogspot). Diaskes 27 maret 2010

3. Direktorat Jendral pengawasan Obat dan Makanan. 1979. Farmakope Indonesi, Edisi III. Departemen Kesehatan Repoblik Indonesia, Jakarta.

4. Gandjar. 2007. Kimia Farmasi Analisis. Himpunan Pelajar, Yogyakarta

5. Ganiswarna Sulistia. 1995. Farmakologi dan terapi. Edisi IV, Fakultas Kedokteran Universitas Indonesia, Jakarta.

6. Hariana, A.H., 2004, Tumbuhan Obat dan Khasiatnya Seri 1, Penerbit Penebar Swadaya, Jakarta.

7. Hensen.1982. Analytical Profiles Of Drug, Substances Volume II. Ediet By Class Academy Press London.

8. Kasryasapoetra, G., dan Marsetyo, H., 2008, Ilmi Gizi (kolerasi gizi dan produksi kerja), PT. Rineka Cipta, Jakarta.

9. Khopkar S. M, 1990. Konsep Dasar Kimia Analitik. Universitas Indonesia. Jakarta.

10. Mulja, M dan Syahrani,A., 1990, Aplikasi Spektrofotometri UVVIS, Mecphiso Grafika, Surabaya.

11. Rangana, S. 1997. Manual Of Analysis of fruit and Vegetable Product. Tata Mc Graw Hill publishing Company, New delhi.

12. Sudjadi. 1988. Analisis Obat dan Makanan. Yayasan Farmasi Indonesia. Jakarta

13. Tjay, T.H. dan Raharja Kirana., 2002. Obat - Obat Penting, Penerbit PT. Elex Media Komputindo, Jakarta.

14. Warisno. 2007. Budi Daya Bengkoang. Penerbit CV, Sinar Cemerlang Abadi. Jakarta 